\title{
Validation of the Turkish version of European Organization for Research and Treatment of Cancer QLQ-OV28 ovarian cancer specific quality of life questionnaire
}

\section{Over kanserli hastalarda hayat kalitesini ölçen Avrupa Kanser Araştırma ve Tedavi Örgütü QLQ-OV28 sorgu formunun Türk toplumuna uyarlanması ve olguların yaşam kalitesinin belirlenmesi}

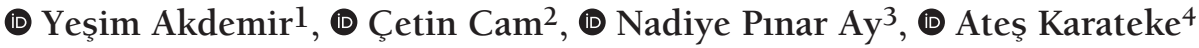 \\ 1Zonguldak Bülent Ecevit University Faculty of Medicine, Department of Obstetrics and Gynecology, Zonguldak, Turkey \\ ${ }^{2}$ Uşak University Faculty of Medicine, Department of Obstetrics and Gynecology, Uşak, Turkey \\ 3 Marmara University Faculty of Medicine, Department of Public Health, İstanbul, Turkey \\ ${ }^{4}$ İstanbul Medeniyet University Faculty of Medicine, Department of Obstetrics and Gynecology, İstanbul, Turkey
}

\begin{abstract}
Objective: To examine reliability and validity of the European Organization for Research and Treatment of Cancer (EORTC) QLQ-OV28 questionnaire into the Turkish language according to the instructions provided by EORTC.

Materials and Methods: Ninety-seven patients who were diagnosed as having ovarian cancer and treated between January 2005 and June 2010 with an expected survival time of at least 3 months, were enrolled into the study. The exclusion criteria were diagnoses of any disease that could disrupt consciousness and concurrent malignancies. The EORTC QLQ-OV28 module was translated into Turkish by professional translators and physicians. The test-retest reliability of the Turkish version of the questionnaire was performed on 30 patients. Answers were scored according to the instructions provided by the EORTC. The total score was calculated as explained above and after scoring procedures, all subscale scores were linearly transformed to a 0-100 scale. All patients concomitantly completed the Spielberg State Trait Anxiety Inventory (STAI) and Beck Depression Inventory (BDI). Patients were analyzed in two groups: on-treatment and off-treatment groups consisted of patients who did and did not undergo chemotherapy or surgery within the last two months, respectively. The demographic data of all patients were recorded. EORTC QLQ-OV28 scores of both groups were compared. Correlations between EORTC QLQ-OV28 subscales and total score of BDI and STAI were analyzed.

Results: For test-retest reliability, Spearman's rho was $0.84(\mathrm{p}<0.001)$. The on-treatment group scored statistically significantly higher than the offtreatment group in peripheral neuropathies, attitude to disease and treatment, sexual function and other chemotherapy adverse effect subscales of the questionnaire. Correlations between EORTC QLQ-OV28 subscales and the total scores of BDI and STAI of the groups were statistically significant, except the sexual function subscale.

Conclusion: The Turkish translated version of EORTC QLQ-OV28 module is a reliable, consistent, and a valid instrument for assessing the impact of treatment modalities on QoL among Turkish speaking women with ovarian cancer.
\end{abstract}

Keywords: Quality of life, ovarian cancer, EORTC

PRECIS: QOL of surviving patients has become an important goal of cancer research and Turkish translated version of EORTC QLQ-OV28 module can help physicians detect the physical and functional effects of disease, the treatment side effects and society/family reactions.

Address for Correspondence/Yazışma Adresi: Yeşim Akdemir, MD,

Zonguldak Bülent Ecevit University Faculty of Medicine, Department of Obstetrics and Gynecology, Zonguldak, Turkey

Phone: +90 5054970407 E-mail: yesimakdemir@yahoo.com ORCID ID: orcid.org/0000-0002-8574-5065

Received/Geliș Tarihi: 20.09.2019 Accepted/Kabul Tarihi: 27.02.2020

The study has been presented as an oral presentation in $16^{\text {th }}$ Turkish Gynecologic and Obstetric Congress, 2018.

${ }^{\oplus}$ Copyright 2020 by Turkish Society of Obstetrics and Gynecology

Turkish Journal of Obstetrics and Gynecology published by Galenos Publishing House. 


\section{$\ddot{\mathrm{O} z}$}

Amaç: Over kanserli hastalarda hayat kalitesini ölçen EORTC QLQ-OV28 sorgu formunun Türk toplumuna uyarlanması.

Gereç ve Yöntemler: Ocak 2005- Ocak 2010 tarihleri arasında Over kanseri tanısı olan, tedavi edilmiș, beklenen sağkalım süresi 3 aydan uzun olan 97 hasta çalışmaya dahil edildi. Eşlik eden başka malignitesi olan ve bilişsel aktiviteyi etkileyecek ek hastalıkları olan hastalar dışlandı. EORTC QLQ-OV28 modülü profesyonel çevirmenler ve hekimler tarafından Türkçe'ye çevrildi. Test-retest güvenilirliği 30 hastadan olușan pilot çalıșma ile yapıldı. Cevaplar EORTC talimatları doğrultusunda puanlandırıldı. Total skorlama yapıldıktan, alt ölçek ve sorulara ait ham puanların hesaplanmasının ardından 0-100 skalasında linear transformasyon uygulandı. Tüm hastalardan eş zamanlı Spielberg State Trait Anxiety Inventory (STAI) and Beck Depression Inventory (BDI) formlarını doldurmaları istendi. Son iki ay içinde kemoterapi almış ya da opere edilmiş hastalar hala tedavi görmekte olan hasta grubu ve son iki ay içinde hiç tedavi almamış hastalar tedavisi bitmiş hasta grubu olarak ayrıldı.

Bulgular: Test-retest güvenilirliği için Spearman's rho 0,84 saptanmıştır ( $\mathrm{p}<0,001)$. Halen tedavi görmekte olan hasta grubunun periferal nöropati, hastalık ve tedaviye karşı tavır, seksüel fonksiyon ve diğer kemoterapi yan etkileri alt ölçekleri skorları tedavisi bitmiş hasta grubunun skorlarından istatistiksel olarak anlamlı oranda yüksek bulunmuştur. EORTC QLQ-OV28 alt ölçekleri ve BDI ve STAI testlerinin total skorları arasındaki korelasyonlar seksüel fonksiyon alt ölçeği dışında istatistiksel olarak anlamlıdır.

Sonuç: Over kanserli hastalarda tedavi modalitelerinin hayat kalitesini üzerine etkilerini değerlendirmek için geliştirilen EORTC QLQ-OV28 sorgu formunun Türkçe versiyonunun tutarlı, güvenilir, uygun yapılandırılmış ve standardize edilmiş bir sorgulama formudur.

Anahtar Kelimeler: Hayat kalitesi, over kanseri, EORTC

\section{Introduction}

Ovarian cancer is a major gynecologic malignancy and the standard treatment is surgery followed by chemotherapy. Over the past 30 years, improvements in cure rates and length of survival have been observed. Five-year survival rates have been reported as high as $90 \%$ for patients diagnosed at stages of localized disease ${ }^{(1)}$. However, although the advances in the treatment of ovarian cancer have significantly improved survival, there remains a cost in terms of unpleasant adverse effects, which reduce the patient's quality of life (QoL). This fact set another aspect in the cancer management beyond survival, and the QoL of surviving patients has become an important goal of cancer research. Inevitably, patient-reported QoL outcome instruments are now more important in cancer-related studies and in evaluating treatment results. An instrument that measures the QoL in these patients should cover the diagnosis of disease, the meaning of disease to the patient, the physical and functional effects of disease, the treatment adverse effects, and society/family reactions ${ }^{(2)}$. The European Organization for Research and Treatment of Cancer (EORTC) developed the EORTC QLQ-OV28, a symptom-specific questionnaire for use in ovarian cancer clinical trials to supplement the EORTC QLQ-C30, a cancer-specific core questionnaire ${ }^{(3)}$. The EORTC QLQ-OV28 module has been translated into many languages and validated in different populations ${ }^{(4)}$.

The current version of EORTC QLQ-OV28 module has been translated into 55 languages as of May 2019 around the world and has also been validated and tested in multicultural settings ${ }^{(5)}$. Although we obtained permission to translate the core questionnaire (OV28) from EORTC QOL Department in 2010, due to incomplete follow-up of permission process, an other Turkish translation of the module was accepted by EORTC QOL Department and is available for use. The current EORTC QLQ-OV28 Turkish module is only a translation without any clinical data and no published literature is available to examine various aspects of EORTC QLQ-OV28 module Turkish version translation and validation process ${ }^{(5)}$. Therefore, the aim of this study was to examine the reliability and validity of this questionnaire into Turkish language according to the instructions provided by EORTC by evaluating the clinical data of 97 patients $^{(6)}$.

\section{Materials and Methods}

\section{Questionnaire}

The EORTC QLQ-OV28 module consists of 28 questions containing symptom scales [abdominal/gastrointestinal symptoms (GI) OV 31-37, peripheral neuropathy (PN) OV 4143 , other chemotherapy adverse effects $(\mathrm{CH})$ OV 38-40, 4447, hormonal/menopausal (HM) OV 48-49, attitude to disease and treatment (AT) OV 52-54, body image (BI) OV 50-51, and Sexual Function scale (SEF) OV 55-58]. Higher scores mean a poorer QoL, whereas for the items of SEF, OV 55-58, higher scores mean better QoL. Therefore, scores of SEF 55-58 need to be reversed during calculations of total scores. Two professional English-Turkish translators, who were not familiar with the EORTC QLQ-OV28, worked independently to produce the Turkish version of the questionnaire. At the first meeting, a common draft of the Turkish version was produced with a list of alternatives for the controversial items and response choices. At the second meeting, between the two translators and Turkish physicians with experience of health and QoL terminology, some revisions were made and a second draft was produced. Ten symptomatic women were asked to self-complete the second draft and then they were interviewed for possible ambiguous questions. At the third meeting, the final Turkish version was completed.

The study was approved by the ethics committee of the medical faculty of İstanbul Zeynep Kamil Women and Child Diseases Training and Research Hospital (approval number: 2019/139). The institutional ethics committee approved the study and informed consent was obtained from each participant. The Turkish version of the full questionnaire is available from the first author on request.

\section{Study population and data collection}

Initially, a pilot study was conducted in order to evaluate 
the internal consistency and the test-retest reliability of the Turkish version of the questionnaire. Women completed the final version at their first visit in the oncology outpatient clinic of Zeynep Kamil Hospital (a tertiary referral teaching institution, Istanbul, Turkey), before meeting a physician. Questionnaires were printed in large fonts (16 font size) in order to be read and self-completed also by patients with poor eyesight. When a patient could not read or write, a relative or an accompanying helper of that patient assisted them in completing the questionnaire, if available. If not, support personnel, not familiar with the concepts of oncology and QoL, provided nondirective assistance to such patients. To measure the test-retest reliability of the final version of the questionnaire, a two-weeks' test-retest analysis was used. Therefore, 30 women were asked to complete the questionnaire at their initial visit and repeat the procedure two weeks later in the same clinic. The responses of the two completed questionnaires were then analyzed using Spearman's correlation test.

After the pilot study, patients who were diagnosed as having ovarian cancer and treated between January 2005 and June 2010 in the same institution, aged between 18-75 years, and with an expected survival time of at least 3 months, were enrolled into the study. The exclusion criteria were diagnoses of any disease that could disrupt consciousness and concurrent malignancies. The participants completed the questionnaire as described above. Answers were scored according to the instructions provided by the EORTC. The total score was calculated as explained above, and after scoring procedures, all subscale scores were linearly transformed to a 0-100 scale.

All patients concomitantly completed the Spielberg State Trait Anxiety Inventory (STAI) and the Beck Depression Inventory $(\mathrm{BDI})^{(7,8)}$. STAI is a 40 -item instrument that differentiates between the temporary condition of 'state anxiety' and the more general and long-standing quality of 'trait anxiety.' The STAI has been adapted into more than 40 languages $^{(7)}$. To evaluate if EORTC QLQ-OV28 is a predicting instrument also for depression, the correlation with BDI was also assessed. The $\mathrm{BDI}$ is a 21-question multiple-choice self-report inventory that is one of the most widely used instruments for measuring the severity of depression. The evaluation of the psychometric properties and cut-off points of the BDI in a Turkish adult population was reported by $\operatorname{Kapci}^{(8)}$.

Patients were prospectively registered into the study and divided into two groups. The on-treatment group consisted of patients who were under chemotherapy or had surgery within the last two months. Patients of the off-treatment group had not received any treatment within the previous two months. The demographic data of all patients were recorded. The EORTC QLQ-OV28 scores of both groups were compared. Correlations between EORTC QLQ-OV28 subscales and total scores of the BDI and STAI were analyzed.

\section{Statistical analysis}

The test-retest reliability was assessed by the Spearman's correlation and Wilcoxon's rank sum tests. A rho value of greater than 0.8 was considered as highly reliable ${ }^{(9)}$. Internal consistencies of the subscales were assessed using Cronbach's alpha coefficient and item to other scale correlations. The content/face validity, which indicates whether the questionnaire makes sense to patients and experts, and whether all the important and relevant domains were included, was assessed by an expert panel that included two urogynecologists and one psychometrician. The levels of the missing data were used as an indicator of inappropriate questions ${ }^{(10)}$. Criterion validity, which describes how well the questionnaire correlates with existing standards ${ }^{(10)}$, was assessed by comparing the EORTC QLQ-OV28 scores with the scores of STAI and BDI. Spearman's correlation coefficient was used for this purpose. All tests were performed using the Statistical Package for the Social Sciences (SPSS) for Windows 11.5. Values are given as percentage (\%) or mean \pm standard deviation (SD). Non-parametric tests were used for the analysis because of the non-normality of the data (Wilcoxon rank and Mann-Whitney U tests). The degree of statistical significance was set at $<0.05$ and all given $p$ values were two-tailed.

\section{Results}

A total of 97 patients who met the inclusion criteria were enrolled in the study. The mean age of the patients was $52.6 \pm 12.6$ years. The on-treatment group comprised 39 patients and the offtreatment group consisted of 58 patients. The sociodemographic and clinical characteristics of the patients are detailed in Table 1.

The number of missing items was zero $(0 \%)$. For the test-retest reliability, Spearman's rho was $0.84(\mathrm{p}<0.001)$. The results of the internal consistency and item to other scale correlations were presented in Table 2 .

Cronbach's alpha values of all scales were higher than 0.70 and these results showed a high level of internal consistency. The on-treatment group scored higher (poorer QoL) than the off-treatment group, and the differences were statistically significant only in the PN, AT, CH, SEF subscales (Table 3). However, when the non-conditional items of SEF subscale (OV55 and OV-56) were analyzed separately, the Cronbach's alpha value was 0.93 . The comparison of the scores of OV-55 and OV-56 of the on- and off-treatment groups were $96.15 \pm 10.44$ and $82.47 \pm 19.60(\mathrm{p}<0.001)$. OV57 and OV58, conditional items to be answered only by sexually active women, were not statistically analyzed because only 50\% (29/58) and 13\% (5/34) of the patients answered these questions in the off- and ontreatment groups, respectively.

The total BDI and STAI scores were $10.4 \pm 8.8$ and $77.2 \pm 19.9$ in both groups, respectively. Correlations between EORTC QLQOV28 subscales and the total scores of BDI and STAI of the groups are presented in Table 4, where all of the correlations were statistically significant except the SEF subscale. 


\section{Discussion}

The results of this study show that the Turkish version of EORTC QLQ-OV28 has a high internal consistency and testretest reliability. Overall, the on-treatment group showed poorer QoL than the off-treatment group. These results might be as a consequence of the heterogeneity of disease stage in the groups (high rates of advanced stages in the on-treatment

Table 1. Sociodemographic and clinical characteristics of the patients

\begin{tabular}{|c|c|c|c|}
\hline \multicolumn{2}{|l|}{$\begin{array}{l}\text { Mean } \pm \text { SD / } \\
\mathrm{n}(\%)\end{array}$} & $\begin{array}{l}\text { On-treatment } \\
(\mathrm{n}=39)\end{array}$ & $\begin{array}{l}\text { Off-treatment } \\
(\mathrm{n}=58)\end{array}$ \\
\hline \multicolumn{2}{|l|}{ Age (Years) } & $57.08 \pm 11.906$ & $49.81 \pm 12.31$ \\
\hline \multirow[t]{3}{*}{ Marital status } & Married & $28(71.8)$ & $47(81)$ \\
\hline & Widowed & $9(23.1)$ & $6(10.3)$ \\
\hline & Single & $2(5.1)$ & $5(6.8)$ \\
\hline \multirow[t]{5}{*}{ Education } & Illiterate & $7(17.9)$ & $5(8.6)$ \\
\hline & Primary & $25(64.1)$ & $36(62.1)$ \\
\hline & Secondary & $1(2.4)$ & $4(6.8)$ \\
\hline & College & $3(7.7)$ & $8(13.8)$ \\
\hline & University & $3(7.7)$ & $5(8.6)$ \\
\hline \multirow[t]{11}{*}{ Disease stage } & Borderline & $0(0.0)$ & $15(25.9)$ \\
\hline & $1 \mathrm{~A}$ & $4(10.3)$ & $10(17.2)$ \\
\hline & $1 \mathrm{~B}$ & $0(0.0)$ & $2(3.4)$ \\
\hline & $1 C$ & $6(15.4)$ & $12(20.7)$ \\
\hline & $2 \mathrm{~A}$ & $2(5.1)$ & $0(0.0)$ \\
\hline & $2 \mathrm{~B}$ & $0(0.0)$ & $1(1.7)$ \\
\hline & $2 C$ & $5(12.8)$ & $2(3.4)$ \\
\hline & $3 \mathrm{~A}$ & $2(5.1)$ & $2(3.4)$ \\
\hline & $3 \mathrm{~B}$ & $1(2.6)$ & $1(1.7)$ \\
\hline & $3 C$ & $15(38.5)$ & $12(20.7)$ \\
\hline & 4 & $4(10.3)$ & $1(1.7)$ \\
\hline \multirow[t]{2}{*}{ Recurrence } & Yes & $4(10.3$ & $4(6.9)$ \\
\hline & No & $35(89.7)$ & $54(93.1)$ \\
\hline \multirow[t]{2}{*}{ Radiotherapy } & Yes & $0(0.0)$ & $2(3.4)$ \\
\hline & No & 39 (100) & $56(96.6)$ \\
\hline \multirow[t]{2}{*}{ Chemotherapy } & Yes & $39(100)$ & $33(56.9)$ \\
\hline & No & $0(0.0)$ & $25(43.1)$ \\
\hline \multirow[t]{2}{*}{ Neoadjuvant } & Yes & $5(12.8)$ & $2(3.4)$ \\
\hline & No & $34(87.2)$ & $56(96.6)$ \\
\hline \multirow[t]{2}{*}{ Colostomy } & Yes & $2(5.1)$ & $0(0.0)$ \\
\hline & No & 37 (94.9) & $58(100)$ \\
\hline
\end{tabular}

SD: Standard deviation group and high rates of borderline and early stages in the offtreatment group).

Similar results were reported in a study providing the validated Taiwan Chinese version of the EORTC QLQ-OV28 ${ }^{(4)}$. Indeed, chemotherapy and/or surgery have an immediate negative effect on QoL and improvements in physical and functional well-being are likely to be observed at later intervals relative to earlier intervals after treatment ${ }^{(11)}$. Women previously treated for gynecologic cancer describe a range of psychosocial difficulties including depression and anxiety, and the most commonly described personal coping strategy is the use of

Table 2. Internal consistency and item to other scale correlation

\begin{tabular}{|c|c|c|}
\hline & $\begin{array}{l}\text { Cronbach's } \\
\text { alpha }\end{array}$ & $\begin{array}{l}\text { Item to } \\
\text { other scale } \\
\text { correlation }\end{array}$ \\
\hline $\begin{array}{l}\text { Abdominal/gastrointestinal } \\
\text { symptoms OV 31-37 }\end{array}$ & 0.78 & $0.026-0.516$ \\
\hline Peripheral Neuropathy OV 41-43 & 0.74 & $0.176-0.692$ \\
\hline $\begin{array}{l}\text { Other chemotherapy side effects } \\
\text { OV } 38-40,44-47\end{array}$ & 0.72 & $0.300-0.693$ \\
\hline Hormonal/menopausal OV 48,49 & 0.82 & $0.081-0.574$ \\
\hline Body image OV 50,51 & 0.81 & $0.034-0.567$ \\
\hline $\begin{array}{l}\text { Attitude to disease and treatment } \\
\text { OV 52-54 }\end{array}$ & 0.87 & $0.012-0.568$ \\
\hline Sexual function OV 55-56* & 0.93 & $0.012-0.300$ \\
\hline
\end{tabular}

Table 3: Comparison of quality of life scores of the European Organization for Research and Treatment of Cancer QLQ-OV28 between the groups (Mann-Whitney U test).

\begin{tabular}{llll} 
& $\begin{array}{l}\text { On-treatment } \\
(\mathbf{n}=39)\end{array}$ & $\begin{array}{l}\text { Off-treatment } \\
(\mathbf{n}=58)\end{array}$ & $\mathrm{p}$ \\
\hline $\begin{array}{l}\text { Abdominal/ } \\
\text { gastrointestinal } \\
\text { symptoms OV 31-37 }\end{array}$ & $24.7 \pm 22.1$ & $19.9 \pm 15.9$ & 0.515 \\
\hline
\end{tabular}

$\begin{array}{lccc}\begin{array}{l}\text { Peripheral neuropathy } \\ \text { OV } 41-43\end{array} & 45.6 \pm 28.3 & 31.4 \pm 28.2 & 0.010^{*} \\ \begin{array}{l}\text { Other chemotherapy } \\ \text { adverse effects (CH }\end{array} & 43.2 \pm 21.5 & 17.2 \pm 15.2 & <0.001 * \\ \text { exclude) OV 38-40, } & & & \\ 44-47 & & & \end{array}$

$44-47$

\begin{tabular}{|c|c|c|c|}
\hline $\begin{array}{l}\text { Hormonal/menopausal } \\
\text { OV 48-49 }\end{array}$ & $45.3 \pm 31.9$ & $35.3 \pm 32.6$ & 0.094 \\
\hline Body image OV 50-51 & $26.1 \pm 32.3$ & $20.7 \pm 26.7$ & 0.451 \\
\hline $\begin{array}{l}\text { Attitude to disease and } \\
\text { treatment OV 52-54 }\end{array}$ & $58.4 \pm 29.0$ & $34.1 \pm 32.4$ & $<0.001^{*}$ \\
\hline $\begin{array}{l}\text { Sexual function OV } \\
55-56^{* *}\end{array}$ & $96.2 \pm 10.4$ & $82.5 \pm 19.6$ & $<0.001 *$ \\
\hline
\end{tabular}


Table 4. Correlations of European Organization for Research and Treatment of Cancer QLQ-OV28 subscales and total score of BDI and STAI between groups (Spearman's correlation test).

\begin{tabular}{|c|c|c|c|c|}
\hline & \multicolumn{2}{|c|}{$\begin{array}{l}\text { BDI total score } \\
\text { data-set }\end{array}$} & \multicolumn{2}{|c|}{$\begin{array}{l}\text { STAI total score } \\
\text { data-set }\end{array}$} \\
\hline & $\mathrm{r}$ & $\mathrm{p}$ & $\mathbf{r}$ & $\mathrm{p}$ \\
\hline $\begin{array}{l}\text { Abdominal/gastrointestinal } \\
\text { symptoms OV } 31-37\end{array}$ & 0.41 & $<0.001^{*}$ & 0.38 & $<0.001 *$ \\
\hline $\begin{array}{l}\text { Peripheral neuropathy OV } \\
41-43\end{array}$ & 0.49 & $<0.001^{*}$ & 0.39 & $<0.001 *$ \\
\hline $\begin{array}{l}\text { Other chemotherapy } \\
\text { adverse effects OV } 38-40 \text {, } \\
44-47\end{array}$ & 0.45 & $<0.001^{*}$ & 0.34 & $0.001 *$ \\
\hline $\begin{array}{l}\text { Hormonal/menopausal OV } \\
48,49\end{array}$ & 0.42 & $<0.001^{*}$ & 0.39 & $<0.001 *$ \\
\hline Body image OV 50,51 & 0.44 & $<0.001^{*}$ & 0.43 & $<0.001 *$ \\
\hline $\begin{array}{l}\text { Attitude to disease and } \\
\text { treatment OV 52-54 }\end{array}$ & 0.61 & $<0.001^{*}$ & 0.55 & $<0.001 *$ \\
\hline $\begin{array}{l}\text { Sexual function OV 55- } \\
56^{* *}\end{array}$ & 0.11 & 0.278 & -0.05 & 0.641 \\
\hline $\begin{array}{l}{ }^{*} \mathrm{p}<0.05 .{ }^{* *} \text { Conditional questions } \\
\text { STAI: Spielberg State Trait Anxiety }\end{array}$ & 57 & ere exclu & 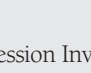 & \\
\hline
\end{tabular}

positive thinking ${ }^{(12)}$. It is obvious that the severity and the discomfort of treatment-related symptoms may affect this attitude. In the present study, patients showed a significant correlation between their decreased QoL and depression and anxiety assessed by BDI and STAI questionnaires, respectively. The SEF subscale contains items pertaining to sexual function and two items (libido and extent of sexual activity) were asked of all patients and the remaining two questions were asked only to those who were sexually active. A significant number of women with gynecologic cancer are not sexually active. Furthermore, in the first phase of the development of the EORTC QLQ-OV28 module, items assessing sexual life had lower ratings than the other items ${ }^{(3)}$. In this study, especially in the on-treatment group, few women answered these items and, contrary to other subscales, significant differences and correlations were not observed in the SEF subscale. This finding was also observed in a study of validation of EORTC QLQ-OV28 into Taiwan Chinese and explained as a result of features of Chinese culture by the authors ${ }^{(4)}$. It should also be noted that in another randomized ovarian cancer study, the EORTC QLQ-OV28 module was designed without the use of these sexual function items ${ }^{(13)}$. Bajpai et al. ${ }^{(14)}$ also showed due to cultural taboos prevalent in India, people feel uncomfortable in talking about sexual behavior in general and a similar observation was noted when patients were asked to respond to question numbers 55-58 in the study of validation of EORTC QLQ-OV28 into Indian languages.

The inconsistency of these items with the module has led to the placement of this subscale at the end of the module, so that it could be omitted without interfering with the other presented items. The decision about neglecting or omitting should be made cautiously because the separate analysis of these nonconditional items of sexual function showed a high consistency and significant difference between the groups in the present study.

\section{Conclusion}

Like the original questionnaire, the Turkish translated version of the EORTC QLQ-OV28 module is a reliable, consistent, and a valid instrument for assessing the impact of treatment modalities on QoL among Turkish-speaking women with ovarian cancer.

\section{Ethics}

Ethics Committee Approval: The study was approved by the ethics committee of the medical faculty of İstanbul Zeynep Kamil Women and Child Diseases Training and Research Hospital (approval number: 2019/139).

Informed Consent: Informed consent was obtained from each participant.

Peer-review: Externally and internally peer-reviewed.

\section{Authorship Contributions}

Concept: Ç.C., Design: N.P.A., Ç.C., Data Collection or Processing: A.K., Analysis or Interpretation: A.K., Writing: Y.A. Conflict of Interest: No conflict of interest was declared by the authors.

Financial Disclosure: The authors declared that this study received no financial support.

\section{References}

1. Altekruse SF, Kosary CL, Krapcho M, Neyman N, Aminou R, Waldron W, Ruhl J, Howlader N, Tatalovich Z, Cho H, Mariotto A, Eisner MP, Lewis DR, Cronin K, Chen HS, Feuer EJ, Stinchcomb DG, Edwards BK (eds). SEER Cancer Statistics Review, 1975-2007, National Cancer Institute. Bethesda, MD.

2. Anderson B, Lutgendorf S. Quality of life as an outcome measure in gynecologic malignancies. Curr Opin Obstet Gynecol 2000;12:21-6.

3. Greimel E, Bottomley A, Cull A, Waldenstrom AC, Arraras J, Chauvenet L, et al. An international field study of the reliability and validity of a disease-specific questionnaire module (the QLQ-OV28) in assessing the quality of life of patients with ovarian cancer. Eur J Cancer 2003;39:1402-8

4. Chie W.-C., Lan, C.-Y., Chiang, C. and Chen, C.-A. Quality of life of patients with ovarian cancer in Taiwan: validation and application of the Taiwan Chinese version of the EORTC QLQ-OV28. Psychooncology 2010;19:782-5.

5. EORTC QLQ-OV28 module. https://qol.eortc.org/questionnaire/ qlq-ov28/ (Available from 20.05.2019)

6. Sprangers MA, Cull A, Groenvold M, Bjordal K, Blazeby J, Aaronson NK. The European Organization for Research and Treatment of Cancer approach to developing questionnaire modules: an update and overview. EORTC Quality of Life Study Group. Qual Life Res. 1998;7:291-300.

7. Ramanaiah NV, Franzen M, Schill T. A psychometric study of the State-Trait Anxiety Inventory. J Pers Assess 1983;47:531-5. 
8. Kapci EG, Uslu R, Turkcapar H, Karaoglan A. Beck Depression Inventory II: evaluation of the psychometric properties and cut-off points in a Turkish adult population. Depress Anxiety 2008;25:E104-10.

9. Fayers P, Aaronson N, Bjordal K, Curan D, Groenvold M. EORTC QLQ-C30 Scoring Manual (2nd edn). RTC Quality of Life Study Group: Brussels, 1999

10. Khullar V. Outcome assessment. In: Bent AE, Ostergard DR, Cundiff GW, Swift SE, (eds.). Ostergard's urogynecology and pelvic floor dysfunction. 5th ed., Philadelphia: Lippincott, Williams \& Wilkins. 2003;51-9.

11. von Gruenigen VE, Frasure HE, Jenison EL, Hopkins MP, Gil KM. Longitudinal assessment of quality of life and lifestyle in newly diagnosed ovarian cancer patients: the roles of surgery and chemotherapy. Gynecol Oncol 2006;103:120-6.
12. Steginga SK, Dunn J. Women's experiences following treatment for gynecologic cancer. Oncol Nurs Forum. 1997;24:1403-8.

13. Cull A, Howat S, Greimel E, Waldenstrom AC, Arraras J, Kudelka A, et al. Development of the European Organization of Research and Treatment of Cancer questionnaire module to assess the quality of life of ovarian cancer patients in clinical trials: a progress report. Eur J Cancer 2001;37:47-53.

14. Bajpai J, Panda PK, Kagwade S, et al. Translation and validation of European Organization for Research and Treatment for Cancer quality of life questionnaire-OV-28 module into Indian languages (Hindi and Marathi) to study quality of life of ovarian cancer patients from a tertiary care cancer center. South Asian J Cancer. 2018;7:37-41 